\begin{tabular}{|l|l|l||}
\hline \multicolumn{2}{|c|}{ PublisherInfo } \\
\hline \hline PublisherName & $:$ & BioMed Central \\
\hline \hline PublisherLocation & $:$ & London \\
\hline \hline PublisherImprintName & $:$ & BioMed Central \\
\hline \hline
\end{tabular}

\title{
700,000 ORESTES
}

\begin{tabular}{|l|l|l||}
\hline \multicolumn{2}{|c|}{ ArticleInfo } \\
\hline \hline ArticleID & $:$ & 4222 \\
\hline \hline ArticleDOI & $:$ & $10.1186 /$ gb-spotlight-20011011-01 \\
\hline \hline ArticleCitationID & $:$ & spotlight-20011011-01 \\
\hline \hline ArticleSequenceNumber & $:$ & 293 \\
\hline \hline ArticleCategory & $:$ & Research news \\
\hline ArticleFirstPage & $:$ & 1 \\
\hline \hline ArticleLastPage & $:$ & 2 \\
\hline \hline & $:$ & RegistrationDate : 2001-10-11 \\
ArticleHistory & $:$ & OnlineDate \\
\hline \hline ArticleCopyright & $:$ & BioMed Central Ltd2001 -10-11 \\
\hline \hline ArticleGrants & $:$ & \\
\hline \hline ArticleContext & $:$ & 130592211 \\
\hline \hline
\end{tabular}




\section{Jonathan B Weitzman}

Email: jonathanweitzman@hotmail.com

Now that we have the whole human genome sequence, the challenge remains to identify all the genes and transcripts hidden within it. In the October 9 Proceedings of the National Academy of Sciences, Anamaria Camargo and colleagues, from the Ludwig Institute for Cancer Research in São Paolo, Brazil, report the results from a Brazilian project aimed at defining the human transcriptome (Proc Natl Acad Sci USA 2001, 98:12103-12108). The approach being used exploits open reading frame expressed sequence tags ORESTES. This differs from the conventional expressed sequence tag (EST) strategy in that it provides sequence information along the whole length of each transcript, rather than just the ends. The method involves low-stringency PCR to produce cDNA libraries, samples of which are then sequenced. Camargo et al. generated almost 700,000 ORESTES from 24 types of normal or malignant tissue using 3,540 mini-libraries. They predict that their ORESTES dataset may represent as many as $60 \%$ of all human genes (including abundant and rare transcripts). The ORESTES approach generates a larger coverage and a greater number of contigs per gene than to standard EST methods, offering the possibility to complete the closure of most sequences using RT-PCR.

\section{References}

1. Proceedings of the National Academy of Sciences, [http://www.pnas.org]

2. Ludwig Institute for Cancer Research , [http://www.ludwig.org.br]

3. Shotgun sequencing of the human transcriptome with ORF expressed sequence tags. 